\title{
EMISSION OF NITROUS OXIDE AND CARBON DIOXIDE FROM SEMI-ARID TROPICAL SOILS IN CHIAPAS MÉXICO(1)
}

\author{
Alejandro Ponce-Mendoza ${ }^{(2,4)}$, Juan Manuel Ceballos-Ramírez ${ }^{(2)}$, \\ Federico Gutierrez-Micelli ${ }^{(3)} \&$ Luc Dendooven ${ }^{(2)}$
}

\begin{abstract}
SUMMARY
The semi-arid region of Chiapas is dominated by $\mathrm{N}_{2}$-fixing shrubs, e.g., Acacia angustissima. Urea-fertilized soil samples under maize were collected from areas covered and uncovered by $A$. angustissima in different seasons and $\mathrm{N}_{2} \mathrm{O}$ and $\mathrm{CO}_{2}$ emissions were monitored. The objective of this study was to determine the effects of urea and of the rainy and dry season on gas emissions from semi-arid soil under laboratory conditions. Urea and soil use had no effect on $\mathrm{CO}_{2}$ production. Nitrons oxide emission from soil was three times higher in the dry than in the rainy season, while urea fertilization doubled emissions. Emissions were twice as high from soil sampled under $A$. angustissima canopy than from arable land, but 1.2 lower than from soil sampled outside the canopy, and five times higher from soil incubated at $40 \%$ of the water-holding capacity (WHC) than at soil moisture content, but 15 times lower than from soil incubated at 100 WHC. It was found that the soil sampling time and water content had a significant effect on $\mathrm{N}_{2} \mathrm{O}$ emissions, while $\mathrm{N}$ fertilizer and sampling location were less influent.
\end{abstract}

Index-terms: Acacia angustissima, denitrification, nitrification, soil water content, urea.

\section{RESUMO: EMISSÕES DE ÓXIDO NITROSO E DIÓXIDO DE CARBONO EM SOLOS TROPICAIS SEMIÁRIDOS DE CHIAPAS - MÉXICO}

A região semiárida de Chiapas é dominada por árvores fixadoras de $\mathrm{N}_{2}$ do tipo Acacia angustissima. Foram analisadas amostras de solos daquela região cultivados com milho, as quais foram coletadas em zonas sob cobertura e em regiões não cobertas por A. angustissima

\footnotetext{
(1) Received for publication in March 2009 and approved in July 2010.

${ }^{(2)}$ Laboratory of Soil Ecology, GIB, Cinvestav, Ciudad de México, México.

(3) Instituto Tecnológico de Tuxtla Gutiérrez, Carr. Panamericana km. 1080, Tuxtla Gutiérrez, Chiapas.

(4) Corresponding author: Tel: (951) 5536362 Ext. 600; E-mail: jano_ponce@hotmail.com. Current address: Universidad de la Sierra Juárez. Av. Universidad S/N Ixtlán de Juárez, Oaxaca. México C.P. 68725
} 


\begin{abstract}
em diversas épocas do ano, às quais foi adicionada ureia. As emissões de $\mathrm{N}_{2} \mathrm{O}$ e $\mathrm{CO}_{2}$ foram monitoradas. A finalidade deste trabalho foi determinar o efeito da uréia, nas épocas secas e de chuvas, sobre as emissões de gases dos solos semiáridos, em condições de laboratório. O solo e a ureia não tiveram efeito na produção de $\mathrm{CO}_{2}$. As emissões de $\mathrm{NO}_{2}$ foram três vezes maiores no solo recolhido na época seca do que no solo recolhido na época úmida, e a adição de ureia duplicou essas emissões. O solo sob a cobertura de A. angustissima apresentou emissões de $\mathrm{NO}_{2}$ duas vezes superiores às do solo arável, porém 1,2 vez inferior à de solo colhido em zonas não cobertas por A. angustissima. Essas emissões foram cinco vezes maiores em solos incubados a $40 \%$ da capacidade de retenção de água (CRA) do que em solo úmido, mas 15 vezes mais baixas do que em solo incubado a $100 \%$ CRA. Foi perceptivel que a época de amostragem e o teor em água do solo tiveram efeito nas emissões de $\mathrm{NO}_{2}$, enquanto o uso de fertilizantes nitrogenados e o local de amostragem tiveram efeito menor.
\end{abstract}

Termos de indexação: Acacia angustissima, desnitrificação, nitrificação, teor de água do solo, ureia.

\section{INTRODUCTION}

Human activities have a large-scale impact on climate, but it is still largely unknown to what extent (Feddema et al., 2005). Although the impact of land use and land cover on the global average surface albedo (biogeophysical effect) and on the atmospheric concentration of carbon dioxide $\left(\mathrm{CO}_{2}\right)$, nitrous oxide $\left(\mathrm{N}_{2} \mathrm{O}\right)$ and methane $\left(\mathrm{CH}_{4}\right)$ has been included in international climate change assessments (IPCC, 2001), less attention has been paid to the role of land use change and differences in regional temperatures, precipitation, vegetation and other climate variables, particularly in arid and semi-arid regions (Pielke, 2005; Keppler et al., 2006).

Approximately $43 \%$ of the continental crust is arid and semi-arid characterized by erratic rainfall, and of these $14 \%$ are tropical savannas and grasslands (FAO, 1997). These regions comprise $13 \%$ of the total global C pool (330 Pg C), whereas the net primary production of $C$ is $30 \%$ (17.7 $\mathrm{Pg} \mathrm{C}$ per year) (Janzen, 2004). Fifty percent of Mexico is arid and semi-arid, mostly in the North of the country (WRI, 2006). However, particular geographical characteristics also determine semi-arid regions in the centre and South of the country. In Chiapas, bordering Guatemala, the main dry area is found in the Central Depression (Chiapas), covering $9,000 \mathrm{~km}^{2}$ (Reyes-García \& Sausa, 1997). The natural vegetation, dominated by $\mathrm{N}_{2}$-fixing shrubs such as $A$. angustissima, is regularly cleared for agriculture. The main traditional cultivation technique used by resource-poor farmers in this area is shifting cultivation agriculture (slash-and-burn) with little application of $\mathrm{N}$, mainly in form of cattle and goat manure, resulting in low yields (ParraVázquez et al., 1989). The use of fertilizer in the regions has increased with the population increase and the change of agriculture techniques (Sagarpa, 2006). In the Central Depression, farmers use urea at low rates because it is cheap (IFA, 2006). The intermittent heavy rain leads to erosion of cultivated land, leaving only shallow soils above the rock. The soil is thus easily saturated, inducing anaerobiosis, which in turn triggers denitrification, the most important source of $\mathrm{N}_{2} \mathrm{O}$, a known greenhouse gas (Bouwman, 1990).

Different factors regulate $\mathrm{N}_{2} \mathrm{O}$ emission, such as soil water content, temperature, aeration, ammonium and nitrate concentrations, the amount of mineralizable $\mathrm{C}$ and $\mathrm{pH}$ (Tiedje, 1988; Bouwman, 1990) so it is highly variable over time. Water-logged soil inhibits $\mathrm{O}_{2}$ diffusion to microorganisms, thus creating an environment favorable for denitrification. This is the main biological process by which $\mathrm{N}$ returns to the atmosphere from the soil and the principal pathway by which the environmental pollutant $\mathrm{N}_{2} \mathrm{O}$ enters the atmosphere (Bouwman, 1990). Emission of greenhouse gases (GHG) from arid and semi-arid regions and the factors affecting it need to be considered when discussing the global gas balances (Squires, 1998) or when defining strategies to mitigate GHG production. GHG emissions from semi-arid soils are lower than from wetlands and agricultural lands, but arid and semiarid ecosystems occupy nearly $45 \%$ of the land surface of the Earth, so their contribution to the overall output is extremely important (FAO, 1997; McLain \& Martens, 2006). There is however little information about GHG emissions from semiarid regions (Wulf et al., 1999) and even less about their contribution from tropical semi-arid regions of Mexico, in spite of covering approximately $1 \times 10^{6} \mathrm{~km}^{2}$ (Solis \& Campo, 2004). In view of the little information available about factors affecting $\mathrm{CO}_{2}$ and $\mathrm{N}_{2} \mathrm{O}$ emissions from semi-arid soils, the $\mathrm{CO}_{2}$ and $\mathrm{N}_{2} \mathrm{O}$ emissions from soil of the Central Depression in Chiapas (Mexico) were investigated under laboratory conditions. Around $25 \%$ of the semi-arid ecosystems are dominated by $\mathrm{N}_{2}$-fixing shrubs of the genera Acacia and Prosopis (Argaw et al., 1999; Geesing et al., 2000). A. angustissima is one of the $\mathrm{N}_{2}$-fixing shrubs that often colonize eroded soil in the Central Depression of Chiapas. Soil was sampled from arable land, but also in the less fertile parts of the Central Depression under A. angustissima, a native $\mathrm{N}_{2}$-fixing shrub dominant, 
and outside its canopy, while $\mathrm{CO}_{2}$ and $\mathrm{N}_{2} \mathrm{O}$ emissions were monitored in an aerobic incubation. The objective of this study was to determine the effect of land use, sampling time (dry or rainy season), and of urea and water on the $\mathrm{N}_{2} \mathrm{O}$ and $\mathrm{CO}_{2}$ emissions in semi-arid soils of the Central Depression.

\section{MATERIAL AND METHODS}

\section{Sampling site}

The sampling sites were located in Copoya, a village in Chiapa de Corzo in the South East of Tuxtla Gutiérrez, State of Chiapas (Mexico) (16 ${ }^{\circ} 38^{\prime}-$ $16^{\circ} 40^{\prime} \mathrm{N}$ and $\left.93^{\circ} 02^{\prime}-93^{\circ} 04^{\prime} \mathrm{W}\right)$ in the Central Depression (Figure 1). The Central Depression is an area of ca. $9,000 \mathrm{~km}^{2}$, with a moderately rugged terrain at 380-1,240 $\mathrm{m}$ asl, where agriculture is the main activity (Reyes-García \& Sausa 1997; Ferrusquía-Villafranca et al., 2000). The mean annual temperature is $27-30^{\circ} \mathrm{C}$ and the average annual precipitation $400 \mathrm{~mm}$, normally not exceeding $600 \mathrm{~mm}$. Rains are concentrated from June through November and rain outside this period is seldom (SMN, 2006). Large amounts of metamorphic rock fragments and some quartz can be found on the soil surface (Ferrusquía-Villafranca et al., 2000). Rocks protect the soil surface and reduce raindrop impact and surface sealing (Abrahams \& Parson, 1991), but limit agricultural activity. Around $50 \%$ of the surface is rock and the thin soil is predominantly Lithosol, 5-15 $\mathrm{cm}$ deep. The region is dominated by short-tree savannah and thorn woodland (Breedlove, 1978), dominated by $A$. angustissima (Timbre) and Byrsonimia crassifolia (Nanche), Swietenia macrophylla (Caobilla), Bucida macrostachya (Cacho de toro), Opuntia spp (Nopal), Acacia farnesiana (Huisache) and bushy old fields or secondary forest (acahuales) can be found in this area (Rzedowski, 1978). Traditionally, Acacia angustissima was used as fuel or for medicinal purposes by local people. Today, these bushes are mixed with agriculture and grasslands in cultivated areas (Rincón-Rosales \& Gutiérrez, 2008).

\section{Soil sampling}

Three different sites were selected and three plots were outlined at each site. In this way, nine different soil samples were obtained, i.e. three soil samples from under the $A$. angustissima trees (UNDER), three from outside the tree canopy (OUT) and three from soil under maize (MAI). The soil was first sampled in the 0-5 cm layer under the canopy of three isolated A. angustissima trees (mean height of $2.5 \mathrm{~m}$ ) at a

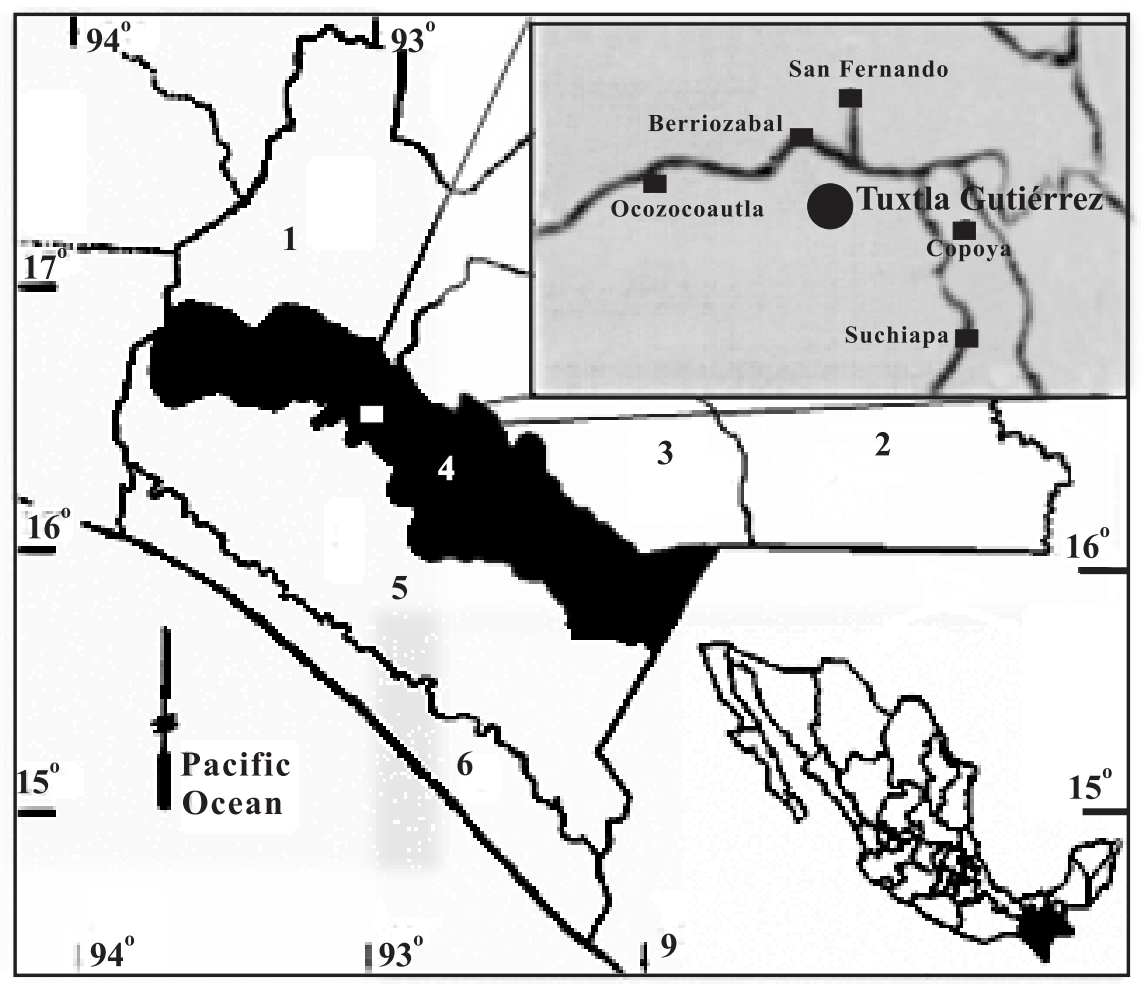

Figure 1. The six different eco-regions in Chiapas State, Mexico with (1) Northern Mountains (2) Eastern Mountains (3) Central High Plains (4) Central Depression (5) Sierra Madre de Chiapas (6) Pacific coastal plains. The small square shows the sampling area in Copoya. 
distance of $1.5 \mathrm{~m}$ from the stem in four randomly selected and pooled perpendicular directions. Secondly, soil was sampled in the $0-5 \mathrm{~cm}$ layer outside the canopy of $A$. angustissima at distances of 2 and $3 \mathrm{~m}$ from the stem of the trees sampled before, under the canopy, in the same perpendicular directions. The shrubs at each site grew within an area of ca. $500 \mathrm{~m}^{2}$. Finally, soil was sampled in the $0-5 \mathrm{~cm}$ layer from three fields cleared of A. angustissima and other shrubs and growing maize for more than 10 years. The fields were located at less than $2 \mathrm{~km}$ from the shrub area. No inorganic fertilizers were applied and maize residues were left on the field, but grazed by cattle and goats. The remaining stover was burned, i.e. a slash-and-burn cultivation. The soil samples from each field were pooled separately for a total of nine samples. Different farmers cultivated each site so that possible effects of cultivation practices could be excluded.

The sampling described above was applied twice, once in April, which is in the dry season and once in August 2004, in the rainy season. In this way, 18 different soil samples were obtained $(n=18)$. Soil was sampled from three different plots at three different locations, i.e. from arable land, and from under and outside the canopy of A. angustissima, in the dry and rainy season.

The percentage of rocks was measured in each plot. Nine quadrants $(3 \times 3 \mathrm{~m})$ were defined in each sampled plot and the diameter of all rocks (considered round) was measured. Six soil depths were randomly measured in each quadrant.

\section{Experimental set-up and treatments}

The soil samples were taken to the laboratory, sieved $(<5 \mathrm{~mm}$ ) and characterized (Table 1). Fortyeight sub-samples of $15 \mathrm{~g}$ dry soil from the 18 soil samples were filled in $120 \mathrm{~mL}$ serum glass bottles. To 12 soil samples a solution was added containing $12 \mathrm{mg} \mathrm{kg-1}$ urea-N dry soil to reach a water content of $40 \%$ water-holding capacity (WHC) and to 12 to reach a water content of $100 \%$ WHC. Twelve samples were adjusted to $40 \% \mathrm{WHC}$ by adding distilled water and 12 to $100 \%$ WHC. The field water content of 12 other samples, called soil moisture content (SMC), was not altered. Nine $120 \mathrm{~mL}$ serum glass bottles were placed in $1000 \mathrm{~mL}$ glass jars containing a $20 \mathrm{~mL}$ glass tube with $10 \mathrm{~mL} 1 \mathrm{~mol} \mathrm{~L}^{-1}$ sodium hydroxide $(\mathrm{NaOH})$ solution to trap evolved $\mathrm{CO}_{2}$ and one with $10 \mathrm{~mL}$ distilled $\mathrm{H}_{2} \mathrm{O}$ to avoid soil desiccation. The jars were sealed airtight and incubated. The remaining three serum glass bottles were closed with a Teflon stopper, sealed with an aluminum tear-off seal $(20 \mathrm{~mm})$ and the headspace analyzed to determine $\mathrm{N}_{2} \mathrm{O}$ in the atmosphere. After two hours, i.e. at the beginning and the end of the $0-2 \mathrm{~h}$ period, the headspace was analyzed again for $\mathrm{N}_{2} \mathrm{O}$.

After one, three and seven days, three jars were randomly selected, opened, the $15 \mathrm{~mL}$ glass tube with $1 \mathrm{~mol} \mathrm{~L}^{-1} \mathrm{NaOH}$ removed and stoppered pending analysis. The $120 \mathrm{~mL}$ serum glass bottles were closed with a Teflon stopper, sealed with an aluminum tearoff seal $(20 \mathrm{~mm})$ and the headspace was analyzed for $\mathrm{N}_{2} \mathrm{O}$ as described before. In this way, $\mathrm{N}_{2} \mathrm{O}$ emissions were measured 24 and $26 \mathrm{~h}$ after the start of the incubation (24-26 h period), after 72 and $74 \mathrm{~h} \mathrm{(72-}$ $74 \mathrm{~h}$ period) and after 168-170 h (168-170 h period). $\mathrm{N}_{2} \mathrm{O}$ emissions were thus measured in four 2 - $\mathrm{h}$ intervals, i.e. between 0 and $2 \mathrm{~h}$, between 24 and $26 \mathrm{~h}$, between 72 and $74 \mathrm{~h}$ and 168 and $170 \mathrm{~h}$. The headspace of the flasks was analyzed for $\mathrm{N}_{2} \mathrm{O}$ on an Agilent Technology 4090D gas chromatograph fitted with an electron capture detector (ECD). A HP-PLOT Q 30 m column where the temperature of the detector, injector and oven were 225,100 and $35^{\circ} \mathrm{C}$, respectively, was used to separate $\mathrm{N}_{2} \mathrm{O}$ from the other gases. The flow of the carrier gas $\mathrm{N}_{2}$ was $6 \mathrm{~mL} \mathrm{~min}^{-1}$. Nitrons oxide dissolved in soil water was determined as described by Moraghan \& Buresh (1977).

The cumulative $\mathrm{CO}_{2}$ was measured in the last three flasks, after seven days, for each treatment. The flasks were opened, the tube with $1 \mathrm{~mol} \mathrm{~L}^{-1} \mathrm{NaOH}$ removed and stoppered before analysis.

\section{$\mathrm{N}_{2} \mathrm{O}$ flux at $100 \% \mathrm{WHC}$}

Twelve 15-g sub-samples from the nine soil samples sampled in the rainy and dry season were filled into $120 \mathrm{~mL}$ serum glass bottle. To half of the

Table 1. Properties of surface soil samples from under and outside the canopy of Acacia angustissima and from soil under maize

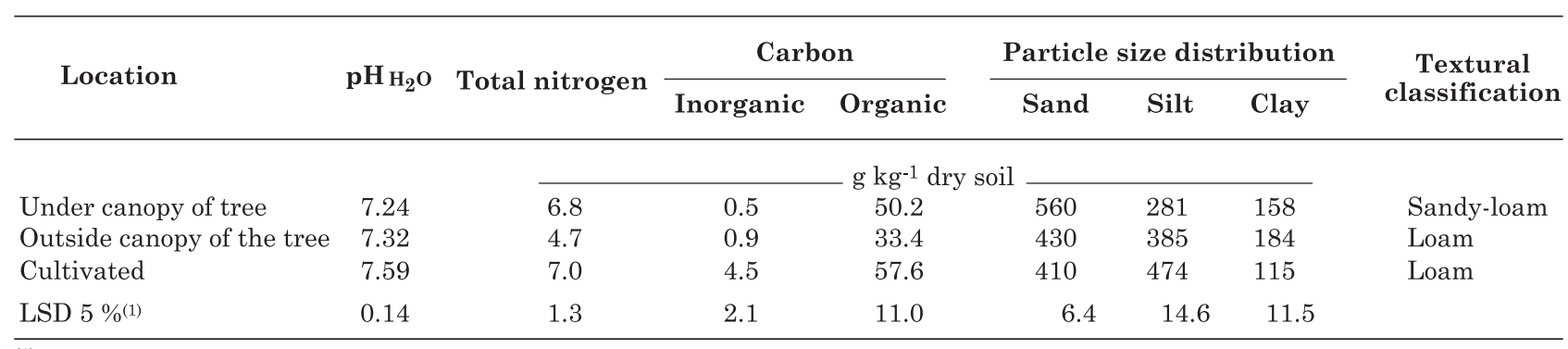

(1) LSD: Least significant difference $(p<0.05)$. 
samples (six) a solution containing $12 \mathrm{mg} \mathrm{kg}^{-1}$ urea$\mathrm{N}$ dry soil was added and to the other half distilled water to complete $100 \%$ WHC. The $120 \mathrm{~mL}$ serum glass bottles were closed with a Teflon stopper and sealed with an aluminium tear-off seal $(20 \mathrm{~mm})$. From half of the flasks of each treatment $12 \mathrm{~mL}$ air was taken and $12 \mathrm{~mL}$ acetylene $\left(\mathrm{C}_{2} \mathrm{H}_{2}\right)$ injected into the headspace (Yoshinari et al., 1977). The headspace was analyzed in the beginning to determine $\mathrm{N}_{2} \mathrm{O}$ in the atmosphere and again after 2, 4 and $6 \mathrm{~h}$.

The $\mathrm{N}_{2} \mathrm{O}$ flux on day zero was calculated using $\mathrm{N}_{2} \mathrm{O}$ production after 2,4 and $6 \mathrm{~h}\left(\mathrm{C}_{2}, \mathrm{C}_{4}\right.$ and $\mathrm{C}_{6}$ respectively). The flux was measured as described by Hutchinson \& Mosier (1981). When the ratio of (C4C2)/(C6-C2) > 1,

$$
\mathrm{F}=\mathrm{k} \times \mathrm{d} \times \frac{273}{\mathrm{~T}} \times \frac{\mathrm{V}}{\mathrm{W}} \times \frac{\left(\mathrm{C}_{4}-\mathrm{C}_{2}\right)^{2}}{\left(2 * \mathrm{C}_{4}-\mathrm{C}_{2}\right) \times \mathrm{t}} \times \ln \frac{\mathrm{C}_{4}-\mathrm{C}_{2}}{\mathrm{C}_{6}-\mathrm{C}_{4}},
$$

where $\mathrm{F}$ is the gas emission rate $\left(\mathrm{ng} \mathrm{kg}^{-1} \mathrm{~h}^{-1} \mathrm{~N}_{2} \mathrm{O}-\mathrm{N}\right.$ soil), $\mathrm{k}$ unit conversion, $\mathrm{d}$ gas density $\left(\mathrm{g} \mathrm{mL}^{-1}\right)$ at 273 $\mathrm{K}$ and $0.101 \mathrm{MPa}$ pressure, $\mathrm{T}$ is the temperature (K) within the bottle, $V$ the headspace of the flask $(\mathrm{mL})$, $\mathrm{W}$ the soil weight in the flask (g dry soil), and $\mathrm{C}$ the gas concentration $\mathrm{ng} \mathrm{mL}^{-1} \mathrm{~N}_{2} \mathrm{O}-\mathrm{N}$ in the headspace, and $\mathrm{t}$ is $2 \mathrm{~h}$ (duration from $\mathrm{C}_{2}$ to $\mathrm{C}_{4}$ ). The value of $\mathrm{d}$ is $1.25 \times 10^{-3} \mathrm{~g} \mathrm{~mL}^{-1}$ for $\mathrm{N}_{2} \mathrm{O}-\mathrm{N}$. Gas density was calculated based on the assumption that $1 \mathrm{~mol}$ of air occupies a volume of $22.4 \mathrm{~L}$ at $273 \mathrm{~K}$ and $0.101 \mathrm{MPa}$.

However, when the gas in the bottle increased $\left(\mathrm{C}_{2}<\mathrm{C}_{4}<\mathrm{C}_{6}\right)$ or decreased over time $\left(\mathrm{C}_{2}>\mathrm{C}_{4}>\mathrm{C}_{6}\right)$ and the ratio of $(\mathrm{C} 4-\mathrm{C} 2) /(\mathrm{C} 6-\mathrm{C} 2) \leq 1$, then the flux was calculated as described by Ginting et al. (2003) from the equation:

$$
\mathrm{F}=\mathrm{k} \times \mathrm{d} \times \frac{273}{\mathrm{~T}} \times \frac{\mathrm{V}}{\mathrm{A}} \times \frac{\Delta \mathrm{C}}{\Delta \mathrm{T}}
$$

Where $\Delta \mathrm{C} / \Delta \mathrm{t}$ is the average rate of concentration variation between $\mathrm{C}_{4}-\mathrm{C}_{2}$ and $\mathrm{C}_{6}-\mathrm{C}_{4}$. The $\mathrm{N}_{2} \mathrm{O}$ flux in the acetylene $\left(\mathrm{C}_{2} \mathrm{H}_{2}\right)$ treatment, (10\% of headspace) was measured in the same way.

The percentage of $\mathrm{N}_{2}$ produced in each treatment was calculated as:

$$
\% \mathrm{~N}_{2}=\frac{\left.\mathrm{N}_{2} \mathrm{O}_{\left(\text {with } \mathrm{C}_{2} \mathrm{H}_{2}\right)}-\mathrm{N}_{2} \mathrm{O} \text { (without } \mathrm{C}_{2} \mathrm{H}_{2}\right)}{\left.\mathrm{N}_{2} \mathrm{O}_{(\text {with }} \mathrm{C}_{2} \mathrm{H}_{2}\right)} \times 100
$$

\section{Soil analysis}

The water holding capacity (WHC) was measured in water-saturated soil samples maintained overnight in a funnel capped to avoid evaporation and left to drain freely. WHC was then defined by weight difference. Soil $\mathrm{pH}$ was measured in 1:2.5 soil- $\mathrm{H}_{2} \mathrm{O}$ suspension using a glass electrode (Thomas, 1996).
Total C was measured with a Shimatzu Total Organic Carbon Analyzer. Inorganic $\mathrm{C}$ in soil was determined by adding $5 \mathrm{~mL} 0.4 \mathrm{~mol} \mathrm{~L}^{-1} \mathrm{HCl}$ solution to $1 \mathrm{~g}$ air-

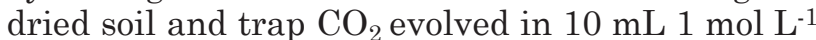
$\mathrm{NaOH}$ and then titrate it with $0.1 \mathrm{~mol} \mathrm{~L}^{-1} \mathrm{HCl}$ to determine $\mathrm{CO}_{2}$ (Jenkinson \& Powlson, 1976). Organic $\mathrm{C}$ was defined as the difference between total $\mathrm{C}$ and inorganic C. Total $\mathrm{N}$ was measured by the Kjeldhal method using concentrated $\mathrm{H}_{2} \mathrm{SO}_{4}, \mathrm{~K}_{2} \mathrm{SO}_{4}$ and $\mathrm{CuSO}_{4}$ to digest the sample (Bremner, 1996) and soil particle size distribution by the hydrometer method as described by Gee \& Bauder (1986). $\mathrm{CO}_{2}$ in $1 \mathrm{~mol} \mathrm{~L}^{-1}$ $\mathrm{NaOH}$ was determined by titration with $0.1 \mathrm{~mol} \mathrm{~L}^{-1}$ $\mathrm{HCl}$ (Jenkinson \& Powlson, 1976).

\section{Statistical analysis}

Cumulative $\mathrm{CO}_{2}$ production was subjected to a factorial analysis of variance using $\mathrm{R}$ (http://cran.rproject.org/) with urea fertilization (treatment) and the different moisture levels as factors. Significant differences between treatments for the cumulative $\mathrm{CO}_{2}$ production were determined using PROC MIXED (SAS, 1989). The log-transformed $\mathrm{N}_{2} \mathrm{O}$ emission data were Box-Cox transformed (Crawley, 2008). The $\mathrm{N}_{2} \mathrm{O}$ values were subjected to factorial analysis of variance using R (http://cran.r-project.org/) with the season, sites, urea fertilization (treatment) and the different moisture levels as factors. The models were simplified until Akaike's Information Criterion values reached a minimum (Crawley, 2008). Soil properties and $\mathrm{N}_{2} \mathrm{O}$ emission rates from the three sites with three replications were subjected to one-way analysis of variance using PROC GLM (SAS, 1989) to test for significant differences between treatments with Tukey's Studentized Range test.

\section{RESULTS}

\section{Soil characteristics}

The organic $\mathrm{C}$ content was greater in arable soil and soil sampled under than outside the canopy of $A$. angustissima (Table 1 ). The amount of rocks was $26 \%$ in arable soil, $42 \%$ in soil under $A$. angustissima and $36 \%$ outside the tree canopy and the mean depth was $6.6,6.0$ and $3.5 \mathrm{~cm}$, respectively.

\section{Cumulative $\mathrm{CO}_{2}$ production rate}

Soil moisture content had no significant effect on the cumulative $\mathrm{CO}_{2}$ production rate from arable soil and soil sampled under and outside the canopy of $A$. angustissima in the rainy season (Figure 2a,b,c). Soil water content, however, had a significant effect on the cumulative $\mathrm{CO}_{2}$ production rate for soil sampled in the dry season (Figure 2d,e,f). It was 3.0 times lower (mean of all treatments) from soil incubated at $100 \%$ WHC and 4.6 times lower for soil at SMC 
compared to soil incubated at $40 \%$ WHC. Urea fertilization had no significant effect on cumulative $\mathrm{CO}_{2}$ production rate (mean of all treatments) (Figure 2). The cumulative $\mathrm{CO}_{2}$ emission rate from soil incubated at $40 \% \mathrm{WHC}$ was 1.3 times higher (mean of all treatments) in the dry than in the rainy season ( $\mathrm{p}<0.05$ ), but 3.0 times lower from soil at SMC (mean of all treatments). The cumulative $\mathrm{CO}_{2}$ production rate was similar in soil sampled under canopy and from arable soil in the rainy and dry season incubated at $100 \%$ WHC (Figure 2a,b,d,e). It was, however, half as high in the dry as in the rainy

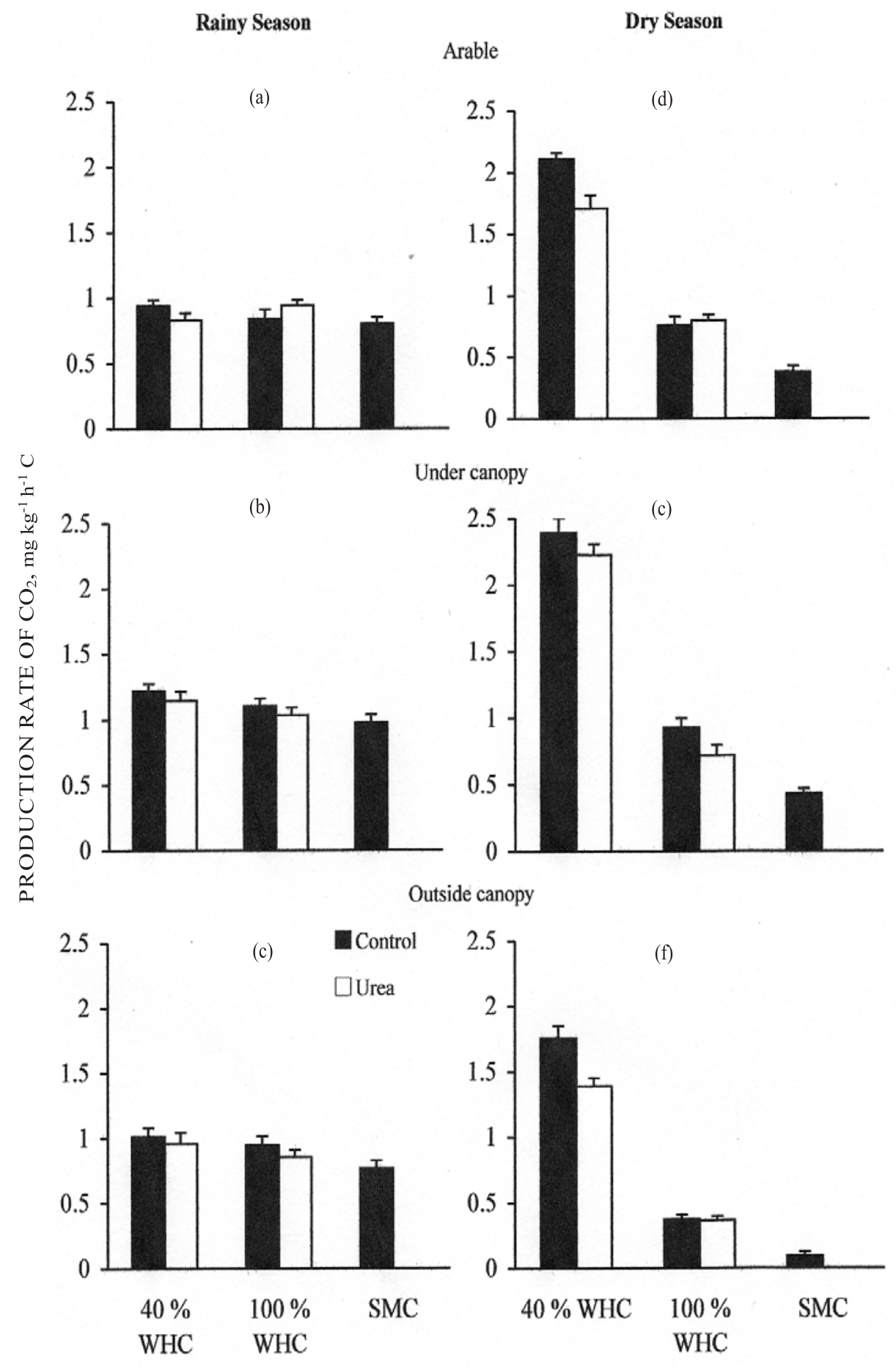

Figure 2. $\mathrm{CO}_{2}$ production rate from soil samples of arable land and of soil under canopy and outside the canopy of Acacia angustissima in the rainy season and dry season amended or not with $12 \mathbf{~ m g ~ k g}^{-1}$ urea$\mathrm{N}$ soil incubated at 40,100\% water-holding capacity (WHC) and soil moisture content (SMC). Bars are standard error of the estimate $(p<0.05)$. 
season for soil sampled outside the canopy of $A$. angustissima. Since urea was applied dissolved in water, no treatment was considered of the SMC soil amended with urea.

\section{$\mathrm{N}_{2} \mathrm{O}$ emission}

The $\mathrm{N}_{2} \mathrm{O}$ emission was significantly affected by season, water content and urea fertilization. $\mathrm{N}_{2} \mathrm{O}$ emissions were 1.5 times higher in the dry than in the rainy season $(p<0.001)$. When the soil was adjusted to $100 \% \mathrm{WHC}, \mathrm{N}_{2} \mathrm{O}$ emissions were twice as high as in soil adjusted to $40 \% \mathrm{WHC}$ and 4.0 times higher than in soil at SMC $(p<0.001)$. Urea fertilization increased $\mathrm{N}_{2} \mathrm{O}$ emissions 1.2 times $(\mathrm{p}<0.001)$. The $\mathrm{N}_{2} \mathrm{O}$ emission from unamended soil sampled in the dry and rainy season incubated at SMC was low and remained at $<8 \mathrm{ng} \mathrm{kg}^{-1} \mathrm{~h}^{-1} \mathrm{~N}_{2} \mathrm{O}-\mathrm{N}$ (Table 2). The $\mathrm{N}_{2} \mathrm{O}$ emission rates were higher for soil sampled in the rainy than in the dry season, except at the start of incubation.

The $\mathrm{N}_{2} \mathrm{O}$ emission from soil incubated at $40 \%$ WHC sampled outside the canopy of $A$. angustissima and from arable soil in the dry season was higher than from soil incubated at SMC (Table 3). It was $233 \mathrm{ng} \mathrm{kg}^{-1} \mathrm{~h}^{-1} \mathrm{~N}_{2} \mathrm{O}-\mathrm{N}$ from arable soil between 24 and $26 \mathrm{~h}$ and $112 \mathrm{ng} \mathrm{kg}^{-1} \mathrm{~h}^{-1} \mathrm{~N}_{2} \mathrm{O}-\mathrm{N}$ from soil sampled outside the canopy between 0 and $2 \mathrm{~h}$. Productions thereafter were lower and similar to soil sampled in the rainy season.

The $\mathrm{N}_{2} \mathrm{O}$ emission in the dry season from unamended and urea-fertilized soil incubated at $100 \%$ WHC was highest in the first 0-2 h (Table 4). Emissions remained high from arable soil and outside the canopy between 24 and 26 h, but decreased under
Table 2. $\mathrm{N}_{2} \mathrm{O}$ emission from arable soil and soil sampled under and outside the canopy of Acacia angustissima in the dry and rainy season incubated at soil moisture content

\begin{tabular}{|c|c|c|}
\hline Time & Dry season & Rainy season \\
\hline \multirow[t]{2}{*}{$\mathrm{h}$} & \multicolumn{2}{|c|}{$\longrightarrow \mathrm{ng} \mathrm{kg}^{-1} \mathrm{~h}^{-1} \mathrm{~N}_{2} \mathrm{O}-\mathrm{N}-$} \\
\hline & \multicolumn{2}{|c|}{ Soil sampled from arable land } \\
\hline $0-\quad 2$ & $5.9(2.2)^{(1)}$ & $2.5(1.1)$ \\
\hline $24-26$ & $0.1(0.4)$ & $0.7(0.6)$ \\
\hline $72-74$ & $0.6(0.7)$ & $1.1(0.6)$ \\
\hline $168-170$ & $0.1(0.2)$ & $3.6(1.1)$ \\
\hline \multicolumn{3}{|c|}{ Soil sampled under canopy of $A$. angustissima } \\
\hline $0-\quad 2$ & $7.5(2.3)$ & $3.8(1.1)$ \\
\hline $24-26$ & $\mathrm{ND}^{(2)}$ & $4.0(0.7)$ \\
\hline $72-74$ & $0.5(1.4)$ & $1.2(0.5)$ \\
\hline $168-170$ & $0.0(0.1)$ & $1.8(0.5)$ \\
\hline \multicolumn{3}{|c|}{ Soil sampled outside canopy of $A$. angustissima } \\
\hline $0-\quad 2$ & $0.2(1.2)$ & $2.0(0.6)$ \\
\hline $24-26$ & $0.7(0.5)$ & $6.0(1.7)$ \\
\hline $72-74$ & $2.3(0.8)$ & $6.6(1.7)$ \\
\hline $168-170$ & $1.0(0.7)$ & $5.5(1.4)$ \\
\hline
\end{tabular}

(1) Values in brackets are standard errors of the estimates. ${ }^{(2)}$ ND: Not determined.

the canopy. The $\mathrm{N}_{2} \mathrm{O}$ emission from soil sampled under and outside the canopy of $A$. angustissima in the rainy season was higher than in the dry season, but not when sampled from arable land.

The $\mathrm{N}_{2} \mathrm{O}$ emission was 2.3 times higher from soil sampled under the canopy of $A$. angustissima compared to soil samples of arable land, but 1.2 lower than from soil sampled outside its canopy. $\mathrm{N}_{2} \mathrm{O}$ production was 5.0 times higher for soil incubated at

Table 3. $\mathrm{N}_{2} \mathrm{O}$ emission from arable soil and soil sampled under and outside the canopy of Acacia angustissima in the dry and rainy season and adjusted to $40 \%$ water-holding capacity

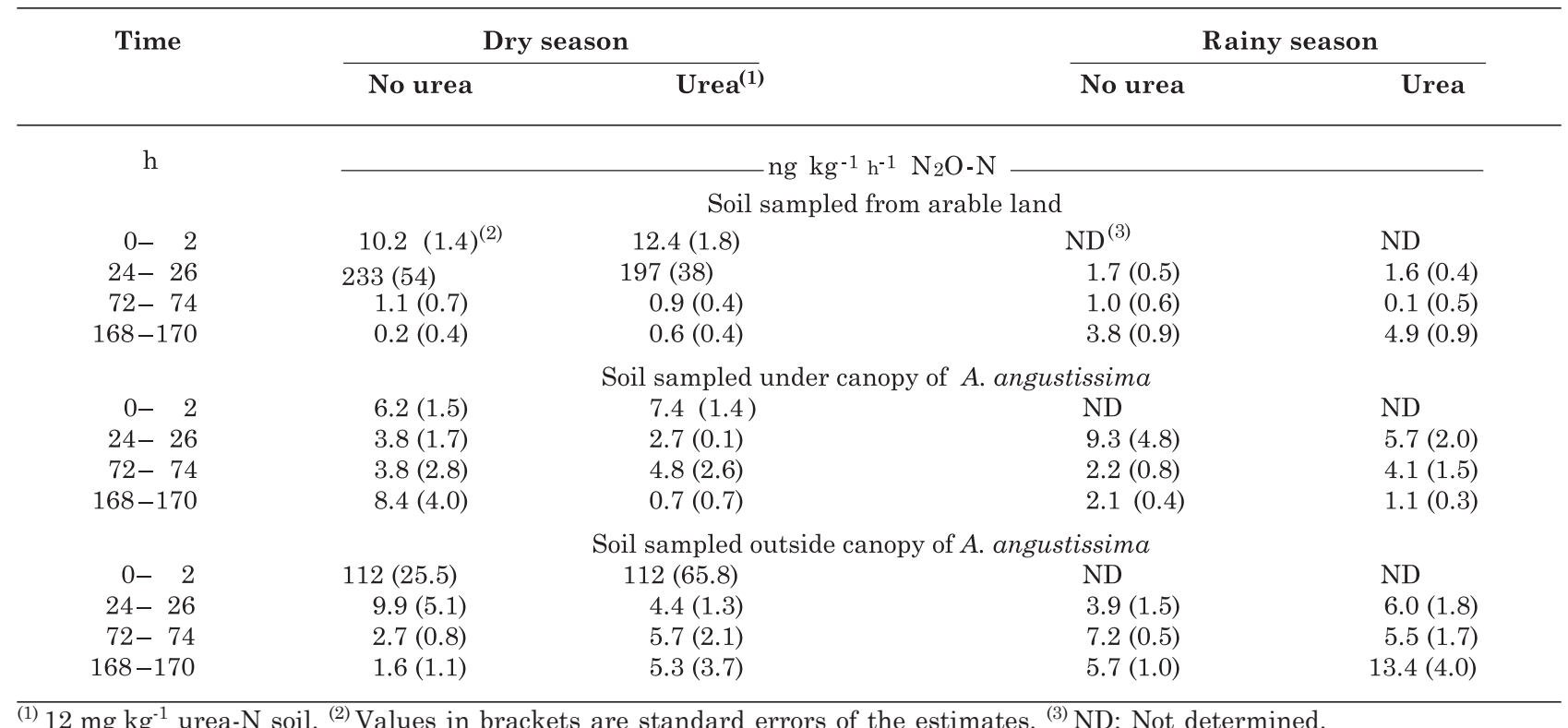

(1) $12 \mathrm{mg} \mathrm{kg}^{-1}$ urea-N soil. ${ }^{(2)}$ Values in brackets are standard errors of the estimates. ${ }^{(3)}$ ND: Not determined. 
$40 \% \mathrm{WHC}$ compared to soil incubated SMC, but 14.5 lower than for soil incubated at $100 \% W H C$. The $\mathrm{N}_{2} \mathrm{O}$ emission $22-24 \mathrm{~h}$ was 5.3 higher than $0-2 \mathrm{~h}, 10.3$ than $72-74 \mathrm{~h}$ and 29.8 times than $168-170 \mathrm{~h}$.

\section{$\mathrm{N}_{2} \mathrm{O}$ flux at $100 \% \mathrm{WHC}$}

Acetylene $\left(\mathrm{C}_{2} \mathrm{H}_{2}\right)$ at $10 \mathrm{kPa} \mathrm{C}_{2} \mathrm{H}_{2}$ is an inhibitor of the reduction of $\mathrm{N}_{2} \mathrm{O}$ to $\mathrm{N}_{2}$. This leads to the $\mathrm{N}_{2} \mathrm{O}$ accumulation as the only end product of the denitrification process. Sampling time and urea fertilization had a significant effect on the $\mathrm{N}_{2} \mathrm{O}$ flux when $\mathrm{C}_{2} \mathrm{H}_{2}$ was added to the headspace, but not the sampling site. The $\mathrm{N}_{2} \mathrm{O}$ flux in the dry was higher than in the rainy season (Table 5). It was 53, 316 and 146 times higher for soil samples of arable land, under canopy and outside canopy in the dry season compared to soil sampled in the rainy season. In general, urea fertilization increased the fluxes of $\mathrm{N}_{2} \mathrm{O}$ in both seasons. In the dry and rainy season, urea fertilization more than doubled $\mathrm{N}_{2} \mathrm{O}$ emission compared to soil with no urea application. The percentage of $\mathrm{N}_{2}$ produced, as a percentage of the emission of $\mathrm{N}_{2}+\mathrm{N}_{2} \mathrm{O}$, was $70 \%$ from unamended soil and $60 \%$ from soil added with urea for both seasons.

\section{DISCUSSION}

\section{$\mathrm{CO}_{2}$ production}

It is usually assumed that most $\mathrm{CO}_{2}$ released into the atmosphere results from soil degradation in tropical and subtropical land, particularly from

Table 4. $\mathrm{N}_{2} \mathrm{O}$ emission from arable soil and soil sampled under and outside the canopy of Acacia angustissima in the dry and rainy season and adjusted to $100 \%$ water-holding capacity

\begin{tabular}{|c|c|c|c|c|}
\hline \multirow[t]{2}{*}{ Time } & \multicolumn{2}{|c|}{ Dry season } & \multicolumn{2}{|c|}{ Rainy season } \\
\hline & No urea & Urea $^{(1)}$ & No urea & Urea \\
\hline \multicolumn{5}{|l|}{$\mathrm{h}$} \\
\hline & \multicolumn{4}{|c|}{ Soil sampled from arable land } \\
\hline $0-\quad 2$ & $230(568)^{(2)}$ & $518(82)$ & $0.4(0.3)$ & $3.5(1.5)$ \\
\hline $24-26$ & $204(80)$ & $339(165)$ & $8.1(1.6)$ & $104(23)$ \\
\hline $72-74$ & $0.2(0.3)$ & $0.0(0.5)$ & $6.6(5.4)$ & $9.3(3.1)$ \\
\hline $168-170$ & $0.3(0.3)$ & $0.9(0.5)$ & $22.4(14)$ & $5.8(1.3)$ \\
\hline \multicolumn{5}{|c|}{ Soil sampled under canopy of $A$. angustissima } \\
\hline $0-2$ & $110(41)$ & $315(86)$ & $3.1(0.9)$ & $10.8(2.4)$ \\
\hline $24-26$ & $0.4(0.6)$ & $1.4(0.8)$ & $2023(707)$ & $1642(741)$ \\
\hline $72-74$ & $1.4(1.1)$ & $1.8(1.2)$ & $34.6(13)$ & $65.9(27)$ \\
\hline $168-170$ & $0.4(0.6)$ & $-0.2(0.3)$ & $9.3(1.1)$ & $13.7(2.2)$ \\
\hline \multicolumn{5}{|c|}{ Soil sampled outside canopy of $A$. angustissima } \\
\hline $0-\quad 2$ & $88(10)$ & $220(18)$ & $0.3(0.8)$ & $6.9(2)$ \\
\hline $24-26$ & $79(42)$ & $129(55)$ & $845(375)$ & $2678(526)$ \\
\hline $72-74$ & $3.2(1.1)$ & $1.5(0.9)$ & $112(27)$ & $546(154)$ \\
\hline $168-170$ & $0.8(0.8)$ & $2.4(1.0)$ & $52(15)$ & $121(37)$ \\
\hline
\end{tabular}

(1) $12 \mathrm{mg} \mathrm{kg}^{-1}$ urea-N soils. ${ }^{(2)}$ Values in brackets are standard errors of the estimates.

Table 5. $\mathrm{N}_{2} \mathrm{O}$ flux from arable soil and from soil sampled under and outside the canopy of Acacia angustissima in the dry and rainy season and adjusted to $100 \%$ water-holding capacity as determined in measurements after $0,2,4$ and $6 \mathrm{~h}$

\begin{tabular}{|c|c|c|c|c|c|}
\hline \multirow[t]{2}{*}{ Site } & \multicolumn{2}{|c|}{ Without acetylene } & & \multicolumn{2}{|c|}{ With acetylene } \\
\hline & No urea & Urea $^{(1)}$ & & No urea & Urea \\
\hline & & 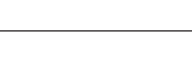 & $\begin{array}{l}\mathrm{kg}^{-1} \mathrm{~h}^{-1} \mathrm{~N}_{2} \mathrm{O}-\mathrm{N} \\
\text { Rainy season }\end{array}$ & & \\
\hline Arable & $29(8)^{(2)}$ & $145(17)$ & & $105(29)$ & $355(54)$ \\
\hline Under Canopy & $5(2)$ & $38(9)$ & & $18(8)$ & $17(7)$ \\
\hline Outside canopy & $1(3)$ & $34(6)$ & & $-3(4)$ & $67(46)$ \\
\hline Arable & $3940(942)$ & $7048(1752)$ & Dry season & $13279(4876)$ & $16972(5463)$ \\
\hline Under Canopy & $3189(141)$ & $10025(3455)$ & & $11589(3577)$ & 23356 (5954) \\
\hline Outside canopy & $1827(214)$ & $3515(1060)$ & & 6698 (2599) & $19142(6247)$ \\
\hline
\end{tabular}

(1) Soil amended with $12 \mathrm{mg} \mathrm{kg}^{-1}$ urea-N soil. ${ }^{(2)}$ Values in brackets are standard errors of the estimates (p < 0.05$)$. 
deforestation and conversion of forest into cropland and cultivated pastures (Fernández et al., 1997; Neill et al., 1998). Conversion of tropical forests to pasture and agricultural land accelerates the turnover of soil $\mathrm{C}$ and $\mathrm{N}$ and increases $\mathrm{N}_{2} \mathrm{O}$ emissions in the short term (Matson \& Vitousek, 1990). However, little attention has been paid to soil $\mathrm{C}$ and $\mathrm{N}$ dynamics in arid or semi-arid regions.

The soil water content at SMC was so low (8\%) that microbial activity was strongly inhibited. Microbial activity is normally considered optimal between $40 \%$ and $60 \%$ WHC (West et al., 1989), and lower water contents inhibit microbial activity (Stark \& Firestone, 1995). At higher water contents, anaerobiosis is induced and $\mathrm{CO}_{2}$ emission is reduced, compared to aerobic conditions (Dendooven \& Anderson, 1995). Additionally, microorganisms need time to adapt to anaerobiosis, so microbial activity is further reduced in soil sampled in the dry season.

The water content at which the soil sampled in the rainy season was incubated, i.e. SMC, $40 \%$ or $100 \%$ WHC, had no significant effect on $\mathrm{CO}_{2}$ production. The moisture content of the soil at SMC, i.e. $35 \%$, was high enough for normal microbial activity and microorganisms in soil incubated at $100 \%$ WHC had time to adapt to the high SMC. Additionally, the previous rainfall events must have stimulated soil microbial biomass activity so that most of the available "easily" decomposable organic material had been mineralized at the time of sampling.

Microbial activity for soil sampled in the dry season as evidenced by $\mathrm{CO}_{2}$ production and incubated at $40 \%$ WHC was twice as high as for soil sampled in the rainy season. The microbial activity in the dry season is lower so easily decomposable organic material accumulates in soil. Addition of water stimulated microbial activity and the decomposition of easily decomposable substrate increased $\mathrm{CO}_{2}$ emission.

Soil appeared not to be $\mathrm{N}$-depleted as urea fertilization did not significantly affect $\mathrm{CO}_{2}$ production. Theoretically, the optimum C:N ratio of organic material for microbial growth is 20-30 (van Veen, 1977). As mentioned above, A. angustissima is a $\mathrm{N}_{2}$ fixing shrub and the $\mathrm{C}: \mathrm{N}$ ratio of the leaves was 20 , providing enough $\mathrm{N}$ for un-inhibited microbial activity.

\section{$\mathrm{N}_{2} \mathrm{O}$ emission}

In semi-arid regions land use is restricted by erratic rainfall (Reyes-García \& Sousa, 1997). Most of the annual precipitation comes from a few rainstorms (Wulf et al., 1999). For instance, strong precipitation $(>20 \mathrm{~mm})$ at the experimental site occurred for only 11 days in 2002 and moderate precipitation (5-20 $\mathrm{mm}$ ) was recorded on 18 days (SMN, 2006). Less than $5 \mathrm{~mm}$ fell in the remaining time. However, these intensive sporadic rainfalls can easily saturate the shallow soil, alter $\mathrm{O}_{2}$ diffusion, microbial activity and consequently $\mathrm{N}_{2} \mathrm{O}$ emissions.
The $\mathrm{O}_{2}$ diffusion was hampered in soil at $100 \%$ WHC so nitrification-denitrification and denitrification were induced, which led to high $\mathrm{N}_{2} \mathrm{O}$ emissions (Wrage et al., 2001). The $\mathrm{N}_{2} \mathrm{O}$ emissions were detected from soil incubated at $40 \% \mathrm{WHC}$, but rates were lower than from soil at $100 \%$ WHC. Soil at $40 \% \mathrm{WHC}$ is well-aerated and nitrification-denitrification and denitrification is inhibited, so $\mathrm{N}_{2} \mathrm{O}$ production occurred mainly through nitrification. However, a high rate of respiratory $\mathrm{O}_{2}$ consumption can result in anaerobic microsites, even at water contents far from saturation as $\mathrm{O}_{2}$ diffusion cannot match consumption (Peterjohn, 1991). Therefore, some part of $\mathrm{N}_{2} \mathrm{O}$ produced at $40 \%$ WHC can be generated by nitrifiers-denitrification or denitrifiers (Wrage et al., 2001).

Soils in semi-arid regions are often low in available nutrients and microbial activity when dry (Vlek et al., 1981). Sporadic but heavy precipitation $(5-20 \mathrm{~mm})$ can easily saturate the shallow soil, alter $\mathrm{O}_{2}$ diffusion, and increase microbial activity and $\mathrm{N}$-mineralization (Sanchez, 1976). Cyclic wetting and drying appears to accentuate denitrification, which strongly correlates with pulses of $\mathrm{C}$ and $\mathrm{N}$ mineralization in the wet-up period (Groffman \& Tiedje, 1988). In this study the highest $\mathrm{N}_{2} \mathrm{O}$ and $\mathrm{N}_{2}$ production was observed in soils sampled in the dry season incubated at $100 \%$ WHC and amended with urea. The $\mathrm{N}_{2}$ emissions, as a percentage of $\left(\mathrm{N}_{2} \mathrm{O}+\mathrm{N}_{2}\right)$ produced, however, were similar in the different treatments. Our data confirm the evidence that on a regional scale, aside from water availability, $\mathrm{N}$ availability may limit net primary $\mathrm{N}_{2} \mathrm{O}$ production in arid and semi-arid ecosystems (Fisher et al., 1988; Gutierrez et al., 1992). Sudden rainfall events rapidly increase the activity of soil organisms thereby stimulating $\mathrm{N}_{2} \mathrm{O}$ emissions (Freckman et al., 1987: Schwinning \& Sala, 2004).

Urea fertilization increases the amount of mineral $\mathrm{N}$ present in the soil, stimulating $\mathrm{N}$ cycling through various pathways (Williams et al., 1998). In this study, urea application to soil at $100 \%$ WHC increased $\mathrm{N}_{2} \mathrm{O}$ production, but not at $40 \%$ WHC. At $100 \%$ WHC, denitrification was induced and nitrification was inhibited, but not necessarily absent. Nitrifiers are microaerophilic, so nitrification and denitrification can take simultaneously (Kuenen \& Robertson, 1994). $\mathrm{NH}_{4}{ }^{+}$is oxidized so that $\mathrm{NO}_{3}{ }^{-}$concentrations increase, which are then reduced so $\mathrm{N}_{2} \mathrm{O}$ emissions increase. Additionally, the nitrifier-denitrification process that occurs in soils with low $\mathrm{O}_{2}$ concentrations also contributes to $\mathrm{N}_{2} \mathrm{O}$ formation (Wrage et al., 2001). Nitrification is normally the process that most contributes to $\mathrm{N}_{2} \mathrm{O}$ production at low water contents, although the contribution in the experiment reported here was rather low. Urea applied to the soil is rapidly hydrolyzed and $\mathrm{NH}_{4}{ }^{+}$concentration increases. $\mathrm{NH}_{4}{ }^{+}$ is then oxidized by nitrifiers so if $\mathrm{N}_{2} \mathrm{O}$ is formed by nitrification, emissions should increase upon urea application. It appears therefore that even at $40 \%$ WHC, most $\mathrm{N}_{2} \mathrm{O}$ production occurred through nitrifier-denitrification or denitrification. As 
mentioned before, despite soil incubation at $40 \% \mathrm{WHC}$ under aerobic conditions, anaerobic micro-sites existed resulting in denitrification and/or nitrifierdenitrification and $\mathrm{N}_{2} \mathrm{O}$ production. Urea application did not increase the amount of anaerobic micro-sites, so $\mathrm{N}_{2} \mathrm{O}$ production did not increase.

The proportion of denitrification gases entering the atmosphere as $\mathrm{N}_{2} \mathrm{O}$ and $\mathrm{N}_{2}$ depends on different environmental factors, such as $\mathrm{pH}, \mathrm{O}_{2}$ availability and $\mathrm{NO}_{3}{ }^{-}$concentration (Firestone et al., 1980; Arah $\&$ Smith, 1990). Independent of the season and sampling area, the ratio $\mathrm{N}_{2} \mathrm{O}_{\left(\text {with } \mathrm{C}_{2} \mathrm{H}_{2}\right)}: \mathrm{N}_{2} \mathrm{O}_{\text {(without } \mathrm{C}_{2} \mathrm{H}_{2} \text { ) }}$ was on average 3.5 for unamended soil and 2.3 for urea-treated soil on day 0 , i.e. urea reduced the percentage of $\mathrm{N}_{2}$ produced. As mentioned above, urea fertilization raises $\mathrm{NO}_{3}{ }^{-}$concentrations even in soil at $100 \% \mathrm{WHC}$, and it is well-known that higher $\mathrm{NO}_{3}$ concentrations in soil increase the $\mathrm{N}_{2} \mathrm{O}: \mathrm{N}_{2}$ gas ratio (Blackmer \& Bremner, 1978; Firestone et al., 1980). Arid regions cover approximately $40 \%$ of the Earth's continental crust and while the estimates for gaseous $\mathrm{N}$ emissions from desert ecosystems are relatively low when compared to tropical ecosystems (Davidson \& Kingerlee, 1997; Hartley \& Schlesinger, 2000), the great extent of arid lands results in the potential for global impacts due to increased $\mathrm{N}$ gas losses from these ecosystems (Schlesinger et al., 1990), mainly in soils rewetted to saturated water conditions after the dry season.

\section{CONCLUSIONS}

In semi-arid regions, such as in the Central Depression of Chiapas, erratic rainfall events control $\mathrm{N}_{2} \mathrm{O}$ and $\mathrm{CO}_{2}$ emissions. From soils at $40 \% \mathrm{WHC}$, i.e. mostly aerobic, $\mathrm{CO}_{2}$ production was high after moistening. Urea fertilization, on the contrary, had no effect on $\mathrm{CO}_{2}$ emission. Moistening the dry soil had a greater effect on $\mathrm{N}_{2} \mathrm{O}$ emission than moistening the wet. Organic material and nutrient accumulation and microbial activity are suppressed in the dry soil, but wetting induces a burst in activity resulting in high $\mathrm{N}_{2} \mathrm{O}$ and $\mathrm{CO}_{2}$ emissions. Moistening stimulates nitrification, and when the soil is wetter nitrifierdenitrification and denitrification thereby increasing $\mathrm{N}_{2} \mathrm{O}$ emissions. The semi-arid regions cover the major part of the Earth's continental crust and changes in their use may have a relevant effect on $\mathrm{CO}_{2}$ and $\mathrm{N}_{2} \mathrm{O}$ emissions and consequently, on greenhouse gas concentrations in the atmosphere.

\section{ACKNOWLEDGEMENTS}

We thank C.A. Lecona-Guzman and L. JiménezRuíz for their help with the field work and the Instituto
Tecnológico de Tuxtla Guiérrez Chiapas for technical and logistic support. We also thank L. Paolino and B. Pereira for the Portuguese translation. The research was funded by Cinvestav while A.P.M. received grant support from Consejo Nacional de Ciencia y Tecnología (CONACyT) Mexico. This study was also benefited by valuable comments and suggestions of the editor and three anonymous reviewers.

\section{LITERATURE CITED}

ABRAHAMS, A.D. \& PARSONS, A.J. Relation between infiltration and stone cover on a semiarid hillslope, southern Arizona. J. Hydrol., 122:49-59, 1991.

ARAH, J.R.M. \& SMITH, K.A. Factors influencing the fraction of the gaseous products of soil denitrification evolved to the atmosphere as nitrous oxide. In: BOUWMAN, A.F., ed. Soils and the greenhouse effect. New York, John Wiley \& Sons, 1990. p.475-480.

ARGAW, M.; TEKETAY, D. \& OLSSON, M. Soil seed flora, germination and regeneration pattern of woody species in an Acacia woodland of the Rift Valley in Ethiopia. J. Arid Environ., 43:411-435, 1999.

BLACKMER, A.M. \& BREMNER, J.M. Inhibitory effect of nitrate on reduction of $\mathrm{N}_{2} \mathrm{O}$ to $\mathrm{N}_{2}$ by soil-microoganisms. Soil Biol. Biochem., 10:187-191, 1978.

BOUWMAN, A.F. Soil and greenhouse effect. New York, Wiley, 1990.

BREEDLOVE, D.E. The phytogeography and vegetation of Chiapas (Mexico). In: GRAHAM, A., ed. Vegetation and history of Northern Latin America. San Francisco, California Academy of Sciences San Francisco, 1978. p.149165.

BREMNER, J.M. Nitrogen total. In: SPARK, D.L., ed. Methods of soil analysis: Chemical methods. Madison, Soil Science Society of America, American Society of Agronomy, 1996. Part 3. p.1085-1122.

CRAWLEY, M.J. The R Book. John Wiley \& Sons, ltd. UK, 2008. p.336-338.

DAVIDSON, E.A. \& KINGERLEE, W. A global inventory of nitric oxide emission from soils. Nutr. Cycl. Agroecosyst., 48, 37-50, 1997.

DENDOOVEN, L. \& ANDERSON, J.M. Use of a 'least-squares' optimization procedure to estimate enzyme characteristics and substrate affinities in the denitrification reactions in soil. Soil Biol. Biochem., 27:1261-1270, 1995.

FAO. State of the world's forests. Rome, 1997.

FEDDEMA, J.J.; OLESON, K.W.; BONAN, G.B.; MEARNS, L.O.; BUJA, L.E.; MEEHL, G.A. \& WASHINGTON, W.M. The importance of land-cover change in simulating future climates. Science, 310:1674-1678, 2005. 
FERNÁNDEZ, E.C.M.; MONTAVALLI, P.P.; CASTILLA, C. \& MUKURUMBIRA, L. Management control of soil organic matter dynamics in tropical land-use systems. Geoderma, 79:49-67, 1997.

FERRUSQUÍA-VILLAFRANCA, I.; APPLEGATE, S.P. \& ESPINOSA-ARRUBARRENA，L. First Paleogene selachifauna of the middle American-Caribbean-Antillean region, La Mesa de Copoya, west-central Chiapas-geologic setting. R. Mexicana Ci. Geol., 17:1-23, 2000.

FIRESTONE, M.K.; FIRESTONE, R.B. \& TIEDJE, J.M. Nitrous-oxide from soil denitrification-factors controlling its biological production. Science, 208:749-751, 1980.

FISHER, F.M.; ZAK, J.C.; CUNNINGHAM, G.L. \& WITHFORD, W.G. Water and nitrogen effects on growth and allocation pattern of creosotebush in the Northern Cihuahuan Desert. J. Range Manag., 41, 387-391, 1988.

FRECKMAN, D.W.; WHITFORD, W.G. \& STEINBERGER, Y. Effect of irrigation on nematode population dynamics and activity in desert soils. Biol. Fert. Soil, 3:3-10, 1987.

GEE, G.W. \& BAUDER, J.W. Particle-size analysis. In: WEBER, R.W.; ANGLE, S.; BOTTOMLEY, P.; BEZDICEK, D.; SMITH, S.; TABATABAI, A. \& WOLLUM, A., eds. Methods of soil analysis; Physical and mineralogical methods. Madison, Soil Science Society of America, 1986. Part 1. p.383-409.

GEESING, D.; FELKER, P. \& BINGHAM, R.L. Influence of mesquite (Prosopis glandulosa) on soil nitrogen and carbon development: Implications for global carbon sequestration. J. Arid Environ., 46:157-180, 2000.

GINTING, D.; KESSAVALOU, A.; EGHBALL, B. \& DORAN, J.W. Greenhouse gas emissions and soil indicators four years after manure and compost applications. J. Environ. Qual., 32:22-32, 2003.

GROFFMAN, P.M \& TIEDJE, J.M. Denitrification hysteresis during wetting and drying cycles in soil. Soil Sci. Soc. Am. J., 52:1626-1629, 1988.

GUTIERREZ, J.R.; AGUILERA, L.E. \& ARMESTO, J.J. The effects of water and macronutrients addition on aboveground biomass production of annual plats in an old field from a coastal desert of north-central Chile. R. Chil. Hist. Nat., 65:83-90, 1992.

HARTLEY, A.E. \& SCHLESINGER, W.H. Environmental controls on nitric oxide emission from Northern Chihuahuan desert soils. Biochemistry, 50:279-300, 2000.

HUTCHINSON, G.L. \& MOSIER, A.R. Improved soil cover method for field measurement of nitrous oxide fluxes. Soil Sci. Soc. Am. J., 45:311-316, 1981.

INTERNATIONAL FERTILIZER INDUSTRY ASSOCIATION - IFA. Access under: <http://www.fertilizer.org/ifa/ statistics/>. Access date: 2006.

INTERGOVERNMENTAL PANEL ON CLIMATE CHANGE - IPCC. Climate change 2001. The scientific basis. Cambridge: Cambridge University Press, 2001.

JANZEN, H.H. Carbon cycling in earth systems-a soil science perspective. Agr. Ecosyst. Environ., 104:399-417, 2004.
JENKINSON, D.S. \& POWLSON, D.S. The effects of biocidal treatments on metabolism in soil I. Fumigation with chloroform. Soil Biol. Biochem., 8:167-177, 1976.

KEPPLER, F.; HAMILTON, J.T.G.; BRASS, M. \& RÖCKMANN, T. Methane emissions from terrestrial plants under aerobic conditions. Nature, 439:187-191, 2006.

KUENEN, J.G. \& ROBERTSON, L.A. Combined nitrificationdenitrification processes. FEMS Microbiol. Rev., 15:109117,1994

MCLAIN, J.E.T. \& MARTENS, D.A. $\mathrm{N}_{2} \mathrm{O}$ production by heterotrophic $\mathrm{N}$ transformations in a semiarid soil. Appl. Soil Ecol., 32:253-263, 2006.

MATSON, P.A. \& VITOUSEK, P.M. Ecosystem approach to a global nitrous-oxide budget. Bioscience, 40:667-671, 1990.

MORAGHAN, J.T. \& BURESH, R. Correction for dissolved nitrous oxide in nitrogen studies. Soil Sci. Soc. Am. J., 41:1201-1203, 1977.

NEILL, C.; CERRI, C.; MELILLO, J.M.; FEIGL, B.J.; STEWUDLER, P.A.; MORAES, J.F.L. \& PICCOLO, M.C. Stocks and dynamics of soil carbon following deforestation for pasture in Rondonia. In: LAL, R.; KIMBLE, J.M.; FOLLET, R.F. \& STEWART, B.A., eds. Soil processes and the carbon cycle. Boca Raton, CRC Press, 1998. p.9-28.

PARRA-VÁZQUEZ， M.R.; ALEMÁN-SANTILLÁN，T.; NAHED-TORAL, J.; MERA-OVANDO, L.M.; LÓPEZMEJÍA, M. \& LÓPEZ-MEZA, A. El subdesarrollo agrícola en los Altos de Chiapas. México, Universidad Autónoma de Chapingo, 1989.

PETERJOHN, W.T. Denitrification: Enzyme content and activity in desert soils. Soil Biol. Biochem., 23:845-855, 1991.

PIELKE R.A. Land use and climate change. Science, 310:1624$1625,2005$.

REYES-GARCÍA, A. \& SAUSA, M. Listado Florístico de México XVII. Depresión Central de Chiapas, la Selva Baja Caducifolia. México, Instituto de Biología, UNAM, 1997.

RINCÓN-ROSALES, R. \& GUTIÉRREZ, F.A. Características biológicas de Acaciella angustissima (mill.) britton \& rose en su habitat natural y evaluación de su potencial cortical en chiapas, méxico / Biological characteristics of Acaciella angustissima (mill.) Britton \& Rose in its natural habitat and assessment of its bark potential in Chiapas, México. Agrociencia, 42:129-137, 2008.

R DEVELOPMENT CORE TEAM, R: A language and environment for statistical computing. $\mathrm{R}$ foundation for statistical computing. Vienna, 2008. Disponível em: <URL http://www.r-project.org>

RZEDOWSKI, J. Vegetación de México. Mexico, D.F., Limusa, 1978.

SECRETARÍA DE AGRICULTURA, GANADERÍA Y DESARROLLO RURAL PESCA Y ALIMENTACIÓN SAGARPA. Access under: <http://www.sagarpa.gob.mx> Access date: 2006.

SANCHEZ, P.A. Properties and management of soil in the tropics. New York, Wiley, 1976. p.618. 
SAS, Institute Inc. Statistic guide for personal computers. Version 6.04, Edition. Cary: 1989.

SCHLESINGER, W.H.; REYNOLDS, J.F.; CUNNINGHAM, G.L.; HUENNEKE, L.F.; JARRELL, W.M.; VIRGINIA, R.A. \& WHITFORD, W.G. Biological feedbacks in global desertification. Science, 247:1043-1047, 1990.

SCHWINNING, S. \& SALA, O.E. Hierarchical organization of resource pulse responses in arid and semiarid ecosystems. Oecologia, 141:211-220, 2004.

SERVICIO METEOROLÓGICO NACIONAL - SMN. Access under < http://smn.cna.gob.mx/> Access date: 2006.

SOLIS, E. \& CAMPO, J. Soil $\mathrm{N}$ and $\mathrm{P}$ dynamics in two secondary tropical dry forests after fertilization. Forest Ecol. Manag.,195:409-418, 2004.

SQUIRES, V.R. Dryland soils: Their potential as a sink for carbon and an agent in mitigating climate change. In: BLUME, H.P.; EGER, H.; FLEISHHAUER, E.; HEBEL, A.; REIJ, C. \& STEINER, K.G., eds. Towards sustainable land use. Reiskirchen: Catena Verlag, 1998. p.209-215. (Advances in Geoecology, 31)

STARK, J.M. \& FIRESTONE, M.K. Mechanisms for soilmoisture effects on activity of nitrifying bacteria. Appl. Environ. Microbiol., 61:218-221, 1995.

THOMAS, G.W. Soil pH and soil acidity. In: SPARKS, D.L., ed. Methods of soil analysis; Chemical methods. Madison, 1996. Part 3. p.475-490. (SSSA Book Series, 5)

TIEDJE, J.M. Ecology of denitrification and dissimilatory nitrate reduction to ammonium, in: ZEHNDER, A.J.B. ed. Biology of anaerobic microorganisms. Wiley, New York, 1988. p.197-244. van VEEN, J.A. The behavior of nitrogen in soil.. Wageningen, Nederland, Landbouwhogeschool, 1977. (Tese de Doutorado)

VLEK, P.L.G.; FILLERY, I.R.P. \& BURFORD, J.R. Accession transformation, and loss of nitrogen in soils of the arid region. Plant Soil, 58:133-175, 1981.

WEST, A.W.; SPARLING, G.P. \& SPEIR, T.W. Microbial activity in gradually dried and rewetted soils as governed by water and substrate availability. Austr. J. Soil Res., 27:747-757, 1989.

WILLIAMS, P.H.; JARVIS, S.C. \& DIXON, E. Emission of nitric oxide and nitrous oxide from soil under field and laboratory conditions. Soil Biol. Biochem., 30:1885-1893, 1998.

WORLD RESOURCE INSTITUTE - WRI. Earth Trends: The Environment Information Portal. Access under: <http:// earthtrends.wri.org/> Access date: 2006.

WRAGE, N.; VELTHOF, G.L.; van BEUSICHEM, M.L. \& OENEMA, O. Role of nitrifier denitrification in the production of nitrous oxide. Soil Biol. Biochem., 33:17231732, 2001.

WULF, S.; LEHMANN, J. \& ZECH, W. Emissions of nitrous oxide from runoff-irrigated and rainfed soils in semiarid north-west Kenya. Agric. Ecosys. Environ., 72:201-205, 1999.

YOSHINARI, T.; HYNES, R. \& KNOWLES, R. Acetylene inhibition of nitrous oxide reduction and measurement of denitrification and nitrogen fixation in soil. Soil Biol. Biochem., 9:177-183, 1977. 